\title{
Diagnosis of blackleg from cattle tissue impregnated in common filter paper
}

\author{
Julia Pires Espíndola ${ }^{*}$ (iD) Luana D’Avila Farias² Cláudia Balzan ${ }^{3}$ (D) \\ Valessa Lunkes Ely ${ }^{1}$ (D) Agueda Palmira Castagna de $\operatorname{Vargas}^{1}$ (iD
}

${ }^{1}$ Programa de Pós-graduação em Medicina Veterinária (PPGMV), Departamento de Medicina Veterinária Preventiva (DMVP), Centro de Ciências Rurais (CCR), Universidade Federal de Santa Maria (UFSM), 97105-900, Santa Maria, RS, Brasil. E-mail: juliapiresesp@gmail.com. ${ }^{*}$ Corresponding author.

${ }^{2}$ Secretaria da Agricultura, Pecuária e Desenvolvimento Rural (SEAPI), Porto Alegre, RS, Brasil.

${ }^{3}$ AFK Imunotech, Passo Fundo, RS, Brasil.

\begin{abstract}
Blackleg, an acute myonecrosis caused by Clostridium chauvoei, is usually underdiagnosed since the rapid transport of adequate samples for laboratory testing is difficult. This study tested a direct polymerase chain reaction (PCR) technique using common filter paper impregnated with cattle tissue samples obtained from animals suspected with blackleg. Twenty-five samples, belonging to eleven animals from Rio Grande do Sul State, Brazil, were analyzed. The direct PCR technique identified eight positive animals corroborating with results from microbiological culture. Skeletal muscle was the most common tissue type used in this study and when the animal was positive the pathogen was always detected in this tissue. Storage time of the impregnated filter paper at room temperature did not prove to be a limiting factor for the quality of the results indicating that this procedure can be carried out in the field and samples be sent in regular mail. Our results suggested that direct PCR of common filter paper impregnated with cattle tissue is a practical and economical alternative for the diagnosis of blackleg. Key words: Clostridium chauvoei; PCR; cattle; blackleg; diagnosis.
\end{abstract}

Diagnóstico de carbúnculo sintomático a partir de papel filtro comum impregnado com tecido bovino

RESUMO: Carbúnculo sintomático, uma mionecrose aguda causada por Clostridium chauvoei, costuma ser subdiagnosticada, pois o transporte rápido de amostras adequadas para exames laboratoriais é complicado. O objetivo deste estudo foi testar a técnica de reação em cadeia da polimerase (PCR) direta, utilizando papel filtro comum impregnado com amostras de tecido bovino obtidas de animais suspeitos de carbúnculo sintomático. Foram analisadas 25 amostras, pertencentes a onze animais do estado do Rio Grande do Sul, Brasil. A técnica de PCR direta identificou oito animais positivos, corroborando com os resultados da cultura microbiológica. O músculo esquelético foi o tecido mais utilizado neste estudo e quando o animal foi positivo, o patógeno sempre foi detectado neste tecido. O tempo de armazenamento do papel filtro impregnado, à temperatura ambiente, não se mostrou um fator limitante para a qualidade dos resultados, indicando que esse procedimento pode ser realizado no local e as amostras enviadas por correio normal. Nossos resultados sugerem que a PCR direta usando papel filtro comum impregnado com tecido bovino é uma alternativa prática e econômica para o diagnóstico de carbúnculo sintomático.

Palavras-chave: Clostridium chauvoei; PCR; bovino; carbúnculo sintomático; diagnóstico.

Blackleg, an acute, non-contagious myonecrosis caused by Clostridium chauvoei, leads to significant losses in the beef cattle industry and is globally responsible for outbreaks and sudden deaths of well-conditioned, young cattle (QUINN et al., 2011). A definitive diagnosis requires the detection of $C$. chauvoei in affected tissues and this is challenging since farmers have to send tissue samples, correctly and on time, to the laboratory and this is usually economically unfeasible (ABREU et al., 2017). In addition, conventional diagnosis using microbiological culture is difficult and time consuming leading to underreporting of the disease (UZAL et al., 2003; ZIECH et al., 2018). Thus, alternative molecular techniques and sampling methods are required to optimize the laboratory diagnosis of blackleg.

Polymerase chain reaction (PCR) is a rapid detection strategy for pathogens. When combined with the tissue-impregnated common filter paper samples it eliminates the need for time-consuming procedures associated with DNA extraction (UZAL 
et al., 2003; MIYASHIRO et al., 2007; ASSIS et al., 2008). Additionally, filter paper is a low-cost material that is easily reported and enables the shipment of samples without refrigeration (KARIMIAN et al., 2011; SMIT et al., 2014).

Previously, detection of C. chauvoei was demonstrated using direct PCR from common filter paper impregnated with bovine liver inoculated with controlled amounts of C. chauvoei strain ATCC 10092 (FARIAS et al., 2012). Based on this, the present study evaluated the use of direct PCR and tissue-impregnated common filter paper for the diagnosis of blackleg in cattle using samples obtained from the field.

Twenty-five samples of bovine tissue from 11 animals belonging to the central region of the Rio Grande do Sul state, Brazil, were sent to the Bacteriology Laboratory of the Universidade Federal de Santa Maria between 2011 and 2017. The animals were between 8 and 18 months of age and had experienced sudden death, suspected to be due to blackleg.

Samples arrived refrigerated, and were immediately used for microbiological culture, which is the standard diagnostic technique in this laboratory. One gram of tissue was inoculated in Reinforced Clostridial Medium (Oxoid Brazil Ltda) and incubated under anaerobic conditions at $37{ }^{\circ} \mathrm{C}$ for 48 h. Ten microlitres were streaked on $5 \%$ sheep blood agar and incubated under anaerobic conditions at 37 ${ }^{\circ} \mathrm{C}$ for $48 \mathrm{~h}$. Colony characteristics and hemolyzing capability of the samples were analyzed. The samples were subjected to Gram staining for morphological determination and to biochemical tests (QUINN et al., 2011). Cultures found to be positive for $C$. chauvoei were confirmed with 16S rRNA gene sequencing (LANE et al., 1991). After microbiological culture, all samples were frozen and stored at $-20^{\circ} \mathrm{C}$.

Direct PCR was performed as described by FARIAS et al. (2012). Common filter paper, $9 \mathrm{~cm}$ in diameter, was impregnated with samples only refrigerated (shortly after arrival) and from thawed samples stored frozen (Table 1) and then the filter paper was stored at room temperature. After the storage period, between one week to one year, three small circular pieces, with an area of approximately $3.14 \mathrm{~mm}^{2}$, were cut out of each impregnated filter paper using Harris Uni-core TM (Electron Microscopy Sciences, Hatfield, PA). The small circular pieces were placed in sterile 0.2 $\mathrm{mL}$ microtubes, covered with $10 \mu \mathrm{L}$ of absolute methanol, and dried in an oven at $37^{\circ} \mathrm{C}$, with no need of extra steps for DNA extraction.

Molecular identification of C. chauvoei involved PCR amplification of the $535 \mathrm{bp} f i C$ gene that encodes flagellin (FliC) according to KOJIMA et al. (2001) and SASAKI et al. (2002). The PCR reaction was performed in a final volume of $25 \mu \mathrm{L}$, containing $2.5 \mu \mathrm{L}$ buffer $10 \mathrm{X}+5 \mu \mathrm{M}$ magnesium chloride, $1 \mu \mathrm{L}$ of each primer at $10 \mu \mathrm{M}, 1 \mu \mathrm{L}$ of dNTP (Ludwig, Brazil), $1 \mu \mathrm{L}$ of template DNA (approximately 50ng) in the positive control and ultrapure distilled water q.s.p. (Invitrogen, USA). All these PCR components were added to the microtubes and heated to $95^{\circ} \mathrm{C}$ for 10 minutes, after that the $\mathrm{GoTaq}^{\circledR}$ DNA Polymerase (Promega, USA) was added in the amount of $0.2 \mu 1$ in each microtube. Microtubes were also reserved for positive and negative controls and PCR for each sample were performed in triplicate (FARIAS et al., 2012).

PCR was carried out in a Veriti 96-well thermal cycler (Applied Biosystems, USA) and the cycling conditions were, initial denaturation of $95^{\circ} \mathrm{C}$ for $5 \mathrm{~min} ; 35$ cycles of $95^{\circ} \mathrm{C}$ for $30 \mathrm{~s} ; 57^{\circ} \mathrm{C}$ for $30 \mathrm{~s}$ and $72{ }^{\circ} \mathrm{C}$ for $1 \mathrm{~min}$ and final extension at $72^{\circ} \mathrm{C}$ for $5 \mathrm{~min}$. The amplified products were electrophoresed and visualized on a $2 \%$ agarose gel stained with ethidium bromide $(0.5 \mu \mathrm{g})$ (FARIAS et al., 2012). To present the results descriptive data analysis was carried out.

The presence of the disease was confirmed in eight animals, while the other three were negative using both techniques. Of the twenty-five samples, fifteen were determined positive for $C$. chauvoei using direct PCR (Table 1). Considering microbiological culture, the same samples were also positive; however, one additional was detected resulting in a total of 16 culture positive samples. Unlike other studies, in this one, when compared to the direct PCR microbiological culture shown higher detection of $C$. chauvoei (UZAL et al., 2003; BAGGE et al.,2009).

The tissue that showed a disagreement between the results of both techniques was the splenic tissue (SB 97), which was positive for the pathogen when cultured upon arrival, but negative using direct PCR when performed two months after filter paper impregnation. This could be a result of low numbers of bacteria that were seen only because of the enrichment in the microbiological culture and were below the detection limit of the direct PCR procedure when applied to the impregnated filter paper. Of note, guinea pigs (Cavia porcellus) that were infected intramuscularly with C. chauvoei, had no bacteria detected in the spleen samples (ASSIS et al., 2005), suggesting that it is not a tissue where the bacteria are usually found.

The types of tissue used for diagnosis of blackleg were skeletal muscle, cardiac muscle, and 
Table 1 - Sample identification history and results of microbiological culture and direct PCR from filter paper.

\begin{tabular}{|c|c|c|c|c|c|c|}
\hline Sample ID & $\begin{array}{l}\text { Bovine } \\
\text { tissue }\end{array}$ & $\begin{array}{c}\text { Year of arrival at } \\
\text { the laboratory }\end{array}$ & $\begin{array}{l}\text { Sample condition before } \\
\text { impregnation }\end{array}$ & $\begin{array}{l}\text { Storage time in } \\
\text { filter paper }\end{array}$ & $\begin{array}{l}\text { Microbiological } \\
\text { Culture }\end{array}$ & $\begin{array}{l}\text { Direct } \\
\text { PCR }\end{array}$ \\
\hline SB 52 & SM 1 & 2011 & Frozen & $2 \mathrm{mos}$ & + & + \\
\hline SB 52 & SM 2 & 2011 & Frozen & $2 \mathrm{mos}$ & + & + \\
\hline SB 75 & SM & 2011 & Frozen & $2 \operatorname{mos}$ & - & - \\
\hline SB 86 & SM 1 & 2011 & Frozen & $2 \mathrm{mos}$ & - & - \\
\hline SB 86 & SM 2 & 2011 & Frozen & $2 \mathrm{mos}$ & - & - \\
\hline SB 97 & SM & 2011 & Frozen & $2 \mathrm{mos}$ & + & + \\
\hline SB 97 & $\mathrm{LT}$ & 2011 & Frozen & $2 \mathrm{mos}$ & - & - \\
\hline SB 97 & $\mathrm{ST}$ & 2011 & Frozen & $2 \mathrm{mos}$ & + & - \\
\hline SB 105 & SM & 2011 & Frozen & $2 \mathrm{mos}$ & + & + \\
\hline SB 105 & ST & 2011 & Frozen & $2 \mathrm{mos}$ & - & - \\
\hline SB 105 & $\mathrm{LT}$ & 2011 & Frozen & $2 \mathrm{mos}$ & + & + \\
\hline SB 25 & SM & 2013 & Frozen & $2 \mathrm{mos}$ & - & - \\
\hline SB 25 & LT & 2013 & Frozen & $2 \mathrm{mos}$ & - & - \\
\hline SB 87285 & SM & 2013 & Refrigerated & $1 \mathrm{y}$ & + & + \\
\hline SB 87285 & $\mathrm{CM}$ & 2013 & Refrigerated & $1 \mathrm{y}$ & + & + \\
\hline SB 87286 & SM & 2013 & Refrigerated & $1 \mathrm{y}$ & + & + \\
\hline SB 87286 & $\mathrm{CM}$ & 2013 & Refrigerated & $1 \mathrm{y}$ & + & + \\
\hline SB 131 & SM 1 & 2013 & Refrigerated & $10 \mathrm{mos}$ & + & + \\
\hline SB 131 & SM 2 & 2013 & Refrigerated & $10 \mathrm{mos}$ & + & + \\
\hline SB 131 & LT & 2013 & Refrigerated & $10 \mathrm{mos}$ & - & - \\
\hline SB 46 & SM & 2014 & Refrigerated & $2 \operatorname{mos}$ & + & + \\
\hline SB 46 & LT & 2014 & Refrigerated & $2 \mathrm{mos}$ & - & - \\
\hline SBP 121 & SM & 2017 & Refrigerated & $1 \mathrm{wk}$ & + & + \\
\hline SBP 121 & $\mathrm{CM}$ & 2017 & Refrigerated & $1 \mathrm{wk}$ & + & + \\
\hline SBP 121 & $\mathrm{LT}$ & 2017 & Refrigerated & $1 \mathrm{wk}$ & + & + \\
\hline
\end{tabular}

y: year; mos: months; wk: week. SB/SBP: laboratory identification; SM: skeletal muscle; LT: liver tissue; CM: cardiac muscle; ST: splenic tissue.

liver tissue. In this study the most common tissue sample (14/25) consisted of skeletal muscle samples, probably due to the ease collection. Furthermore, when multiple tissue were sent per animal, the skeletal muscle sample was always positive for the pathogen (SB 97, SB 105, SB 87, SB 131, SB 46, and SBP 121), suggesting that the skeletal muscle may be the preferred tissue sample for this diagnostic test.

Corroborating these results, skeletal muscle samples from dead cattle with blackleg have shown a higher amount of $C$. chauvoei compared to other organs (BAGGE et al., 2009; ASSIS et al., 2010). The cardiac muscle was also always positive for the pathogen, and the detection of lesions and bacteria in the heart is considered a visceral case. This is not a common or widely reported finding in Brazil. Thus, this sample should preferably be sent, when there are lesions in the myocardium, along with other tissues for laboratory diagnosis (UZAL et al., 2003; ASSIS et al., 2010; CASAGRANDE et al., 2015).

The filter paper impregnated with different samples varied in storage time, from one week to one year, at room temperature. Most of these samples were stored for more than two months, and $96 \%$ of the samples showed the same result as the microbiological culture. Until now, FARIAS et al. (2012) analyzed only samples stored for one week. Four samples were positive after one year of storage at room temperature, suggesting that the common filter paper can potentially preserve the DNA of C. chauvoei. Our results were similar to that of KARIMIAN et al. (2011), where filter paper cards were used to store blood and bacteria for up to twelve months. In another study, filter paper was used to store the African swine fever virus, for up to 9 months, at $20-25{ }^{\circ} \mathrm{C}$, and for 2 months at $37^{\circ} \mathrm{C}$, 
without a significant loss in detection sensitivity (RANDRIAMPARANY et al., 2016).

A total of $83 \%$ of the samples that were only refrigerated before impregnation and $38.46 \%$ of samples frozen until impregnation, were positive using PCR. All of these samples were culture positive suggesting that the type of storage before impregnation did not interfere with the results.

Advantages of this technique included the easy impregnation of samples by veterinarians or farm owners, low-cost of common filter paper, and the use of normal postal service, without cold storage, for the shipment of samples to the laboratory (SMIT et al., 2014; MATHEUS et al., 2015). As a result, laboratory diagnosis becomes faster, without the need of other techniques to aid in the survival, growth, and enrichment of the bacteria for PCR (MIYASHIRO et al., 2007; ASSIS et al., 2008).

Finally, it was demonstrated the use of direct PCR on tissue-impregnated common filter paper to identify $C$. chauvoei in bovine tissue samples. This method can serve as a diagnostic technique for blackleg using routine samples of skeletal muscle, cardiac muscle, and liver tissue. Our results suggested that it is a practical, economical, and efficient alternative for the collection and transport of tissue and will help reduce the under diagnosis of this important disease.

\section{ACKNOWLEDGEMENTS}

This study was financed in part by the Coordenação de Aperfeiçoamento de Pessoal de Nível Superior (CAPES) (finance code 001 and scholarship 88881.189294/2018-01/PDSE) and by Fundação de Amparo à Pesquisa do Estado do Rio Grande do Sul (FAPERGS).

\section{DECLARATION OF CONFLICT OF} INTEREST

The authors declare no conflict of interest. The founding sponsors had no role in the design of the study; in the collection, analyses, or interpretation of data; in the writing of the manuscript, and in the decision to publish the results.

\section{AUTHORS' CONTRIBUTIONS}

The authors contributed equally to the manuscript.

\section{REFERENCES}

ABREU, C. C. et al. Blackleg in cattle: A case report of fetal infection and a literature review. Journal of Veterinary Diagnostic Investigation, v.29, n.5, p.612-621, 2017. Available from: <https://pubmed.ncbi.nlm.nih.gov/28599620/>. Accessed: May, 20, 2020. doi: 10.1177/1040638717713796.
ASSIS, R. A. de et al. PCR detection of Clostridium chauvoei in tissues of Cavia porcellus. Pesquisa Agropecuária Brasileira, v.40, n.12, p.1247-1250, 2005. Available from: $<$ https://www.scielo. $\mathrm{br} / \mathrm{scielo}$.php?pid=S0100-204X2005001200014\&script $=$ sci abstract\&tlng $=$ pt $>$. Accessed: Jul. 20, 2020. doi: 10.1590/S0100204X2005001200014.

ASSIS, R. A. et al. Multiplex PCR for identification of Clostridium chauvoei and Clostridium septicum. Arquivo brasileiro de Medicina Veterinária e Zootecnia, v.60, n.2, p.294-298, 2008. Available from: <https:/www.scielo.br/scielo.php?script=sci arttext\&pid=S0102-09352008000200003 > Accessed: Jul. 25, 2020. doi: 10.1590/S0102-09352008000200003.

ASSIS, R. A. et al. Bovine clostridial myonecrosis. Arq. Inst. Biol., São Paulo, v.77, n.2, p.331-334, 2010. Available from: $<\mathrm{http} / / /$ www.biologico.sp.gov.br/uploads/docs/arq/v77_2/assis. pdf $>$. Accessed: Sep. 2, 2020.

BAGGE, E. et al. Detection and identification by PCR of Clostridium chauvoei in clinical isolates, bovine feces and substrates from biogas plant. Acta Veterinaria Scandinavica v.51, n.8,2009. Available from: <https://pubmed.ncbi.nlm.nih. gov/19257884/>. Accessed: Mar. 10, 2020. doi: 10.1186/17510147-51-8.

CASAGRANDE, R. A. et al. Histopathological, immunohistochemical and biomolecular diagnosis of myocarditis due to Clostridium chauvoei in a bovine. Ciência Rural, v.45, n.8, p.1472-1475, 2015. Available from: <https://www.scielo. br/scielo.php?pid=S0103-84782015000801472\&script=sci arttext\&tlng=en>. Accessed: Jul. 25, 2020. doi: 10.1590/0103$8478 \mathrm{cr} 20141447$.

FARIAS, L. et al. Molecular Identification of Clostridium chauvoei from Common Filter Paper. Acta Scientiae Veterinariae, v.40, n.4, p.1-5, 2012. Available from: <http://www.ufrgs.br/actavet/40-4/ PUB\%201075.pdf $>$. Accessed: Mar. 10, 2020. doi: 10.1590/0103$8478 \mathrm{cr} 20170939$.

KARIMIAN, F. S. et al. Utility of filter paper for preserving insects, bacteria, and host reservoir DNA for molecular testing. Iranian Journal of Arthropod-borne Diseases, v.5, n.2, p.42-50,2011. Available from: <https://pubmed.ncbi.nlm.nih.gov/22808417/>. Accessed: Mar. 10, 2020.

KOJIMA, A. et al. Rapid detection and identification of Clostridium chauvoei by PCR based on flagellin gene sequence. Veterinary Microbiology, v.78, p.363-371, 2001. Available from: <https:// pubmed.ncbi.nlm.nih.gov/11182502/>. Accessed: Mar. 10, 2020. doi: 10.1016/s0378-1135(00)00339-4.

LANE, D. J. 16S/23S rRNA sequencing. In: STACKEBRANDT, E.; GOODFELLOW, M. Nucleic Acid Techniques in Bacterial Systematics. New York: Wiley, 1991. Chap.6, p.115-175.

MATHEUS, S. et al. The use of serum spotted onto filter paper for diagnosing and monitoring Chikungunya virus infection. Journal of Clinical Virology, v.71, p.89-92, 2015. Available from: <https:// pubmed.ncbi.nlm.nih.gov/26339948/>. Accessed: Jul. 30, 2020. doi: 10.1016/j.jcv.2015.08.008.

MIYASHIRO, S. et al. Identification of Clostridium chauvoei in clinical samples cultures from blackleg cases by means of PCR. Brazilian Journal of Microbiology, v.38, n.3, p.491-493, 2007. Available from: <https://www.scielo.br/scielo.php?script=sci_ 
arttext\&pid $=\mathrm{S} 1517-83822007000300020>$. Accessed: Sep. 20, 2020. doi: S1517-83822007000300020.

QUINN, P.J. et al. Clostridium species. In: Veterinary microbiology and microbial disease. 2. ed. Iowa: WileyBlackwell, 2011. Chap. 22, p. 618-663.

RANDRIAMPARANY, T. et al. African Swine fever diagnosis adapted to tropical conditions by the use of dried-blood filter papers. Transboundary and Emerging Diseases, v.63, n.4, p.379-388, 2016. Available from: < https://pubmed.ncbi.nlm.nih. gov/25430732/>. Accessed: Sep. 20, 2020. doi: 10.1111/tbed.12295.

SASAKI, Y. et al. Phylogenetic analysis and PCR detection of Clostridium chauvoei, Clostridium haemolyticum, Clostridium novyi types $\mathrm{A}$ and $\mathrm{B}$, and Clostridium septicum based on the flagellin gene. Veterinary Microbiology, v.86, p.257-267, 2002. Available from: <https://pubmed.ncbi.nlm.nih.gov/11900959/> Accessed: Mar. 15, 2020. doi: 10.1016/s0378-1135(02)00002-0.
SMIT, P. W. et al. An overview of the clinical use of filter paper in the diagnosis of tropical diseases. The American Journal of Tropical Medicine and Hygiene, v.90, n.2, p.195-210, 2014. Available from: <https://www.ncbi.nlm.nih.gov/pmc/articles/ PMC3919219/>. Accessed: May, 18, 2020. doi: 10.4269/ ajtmh.13-0463.

UZAL, F.A. et al. PCR detection of Clostridium chauvoei in pure cultures and in formalin-fixed, paraffin-embedded tissues. Veterinary Microbiology, v.91, n.2-3, p.239-248, 2003. Available from: <https://pubmed.ncbi.nlm.nih.gov/12458172/>. Accessed: May, 10, 2020. doi: 10.1016/s0378-1135(02)00291-2.

ZIECH, R. E. et al. Blackleg in cattle: current understanding and future research needs. Ciência Rural, v.48, n.5, e20170939, 2018. Available from: <https://www.scielo.br/scielo.php?pid=S0103$84782018000500454 \&$ script $=$ sci_abstract\&tlng $=$ pt $>$. Accessed: Mar. 15, 2020. doi: 10.1590/0103-8478cr20170939. 